Article

\title{
Buffer anion effects on water oxidation catalysis: The case of $\mathrm{Cu}$ (III) complex
}

\author{
Qifa Chen, Haoyi Du, Mingtian Zhang * \\ Center of Basic Molecular Science (CBMS), Department of Chemistry, Tsinghua University, Beijing 100084, China
}

\section{A R T I C L E I N F O}

\section{Article history:}

Received 5 September 2020

Accepted 14 October 2020

Available online 5 April 2021

\section{Keywords:}

Artificial photosynthesis

Water oxidation

Redox-active ligand

Copper catalyst

Buffer anion effect

\begin{abstract}
A B S T R A C T
Water oxidation is the bottleneck of artificial photosynthesis. Since the first ruthenium-based molecular water oxidation catalyst, the blue dimer, was reported by Meyer's group in 1982, catalysts based on transition metals have been widely employed to explore the mechanism of water oxidation. Because the oxidation of water requires harsh oxidative conditions, the stability of transition complexes under the relevant catalytic conditions has always been a challenge. In this work, we report the redox properties of a $\mathrm{Cu}^{\mathrm{III}}$ complex (TAML-Cu ${ }^{\mathrm{III}}$ ) with a redox-active macrocyclic ligand (TAML) and its reactivity toward catalytic water oxidation. TAML-Cu ${ }^{\text {III }}$ displayed a completely different electrochemical behavior from that of the TAML-CoIII complex previously reported by our

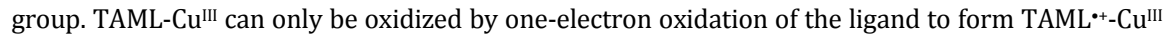
and cannot achieve water activation through the ligand-centered proton-coupled electron transfer

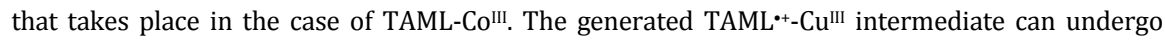
further oxidation and ligand hydrolysis with the assistance of borate anions, triggering the formation of a heterogeneous $\mathrm{B} / \mathrm{CuO}_{x}$ nanocatalyst. Therefore, the choice of the buffer solution has a significant influence on the electrochemical behavior and stability of molecular water oxidation catalysts.
\end{abstract}

(C) 2021, Dalian Institute of Chemical Physics, Chinese Academy of Sciences. Published by Elsevier B.V. All rights reserved.

\section{Introduction}

Splitting water into hydrogen and oxygen by an artificial photosystem remains a challenge in chemistry [1-3] because of the complexity of water oxidation [4-6], which requires a four-electron transfer and the rearrangement of multiple bonds. Molecular transition-metal catalysts have been extensively developed [7-35] for understanding this four-electron oxidation process, since the first complex capable of mediating water oxidation was reported in 1982 by Meyer's group [36]. Considering that harsh oxidative conditions are necessary for oxidizing water to oxygen, a "safe condition" that can ensure the stability of the catalyst is always expected [37-42]. Howev- er, the initial molecular complexes frequently undergo an irreversible transformation into heterogeneous $\mathrm{M}_{x} \mathrm{O}_{y}$, because of the formation of damaging high-energy intermediates that can decompose into catalytically active heterogeneous species [43-46]. Inspired by this conversion of molecular species to heterogeneous catalysts, the use of molecular pre-catalysts to prepare active heterogeneous nanomaterials for catalyzing water oxidation has received extensive attention [47]. Understanding the factors controlling the in situ transformation between a homogeneous molecular catalyst and heterogeneous active species is vital for molecular design. In this work, we investigated the redox properties of a $\mathrm{Cu}^{\mathrm{III}}$ complex with a redox-active macrocyclic ligand (TAML) and its reactivity toward

\footnotetext{
* Corresponding author. Tel: +86-10-62783624; E-mail: mtzhang@mail.tsinghua.edu.cn
} 
water oxidation. Unlike the TAML-Co ${ }^{\text {III }}$ complex [23], which could catalyze water oxidation to generate $\mathrm{O}_{2}$ with the assistance of a redox-active ligand, the TAML-CuIII compound investigated in this study does not exhibit catalytic water oxidation activity in either phosphate buffer (PBS) or sodium bicarbonate $\left(\mathrm{NaHCO}_{3}\right)$ solution. On the other hand, borate buffer (BB) could trigger the generation of a heterogeneous active species $\left(\mathrm{B} / \mathrm{CuO}_{x}\right)$ by a macrocyclic ligand open-ring reaction, catalyzing water oxidation.

\section{Experimental}

\subsection{Materials}

All chemicals involved in this study, except the TAML ligand and the TAML-CuII complex, were purchased from commercial suppliers and used without further purification, unless otherwise specified. Purified deionized water was prepared using a Milli-Q Ultrapure water purification system.

\subsection{Instrumentation}

NMR spectra of the compounds and complexes investigated in this study were measured using a Bruker AVANCE III HD 400 spectrometer $\left({ }^{1} \mathrm{H}: 400 \mathrm{MHz} ;{ }^{13} \mathrm{C}\right.$ : $\left.100 \mathrm{MHz}\right)$. ESI-HRMS data were recorded on an LCMS-IT/TOF (Shimadzu, Japan) spectrometer. FESEM images were collected on a QUANTA 200 FEG (FEI Company) microscope. X-ray photoelectron spectroscopy (XPS) data were recorded on an ESCALAB 250Xi (Thermo Fisher) spectrometer.

All electrochemical data were collected on a CHI-630 electrochemical workstation, using a three-electrode system: the working electrode (WE) consisted of boron-doped diamond (BDD, $0.07 \mathrm{~cm}^{2}$ ) or indium tin oxide (ITO, $1 \mathrm{~cm}^{2}$ ); platinum wire and saturated calomel electrode (SCE) were used as the counter electrode (CE) and reference electrode (RE), respectively. Before the electrochemical experiments, the BDD electrode was polished continuously with $0.3-$ and $0.05-\mu \mathrm{m}$ alumina, then washed and cleaned with deionized water. Finally, the polished BDD electrode was placed in phosphate buffer $(0.1 \mathrm{M}$, $\mathrm{pH} 7$ ) and subjected to multiple cyclic voltammetry (CV) scans at 0-1.64 V vs. normal hydrogen electrode (NHE) before use. CV and controlled potential electrolysis (CPE) experiments were both carried out in borate buffer (0.2 M, pH 9) at room temperature; all potentials involved in this work were recorded $v s$. NHE, unless otherwise stated.

\subsection{Synthesis and characterizations of TAML-CUIII}

The TAML ligand was synthesized according to a literature procedure, with few modifications [48,49]. Characterization of TAML: ${ }^{1} \mathrm{H}$ NMR (d6-DMSO): $\delta 8.28(\mathrm{~s}, 2 \mathrm{H}), 7.75(\mathrm{~s}, 2 \mathrm{H})$, 7.45-7.47 (dd, 2H), 7.16-7.18 (dd, 2H), 1.47 (s, 12H), 1.45 (s, $6 \mathrm{H}$ ). HRMS (positive mode): calculated $\mathrm{m} / z$ for $\mathrm{C}_{19} \mathrm{H}_{26} \mathrm{~N}_{4} \mathrm{O}_{4} \mathrm{Na}$ : 397.1852 $[\mathrm{M}+\mathrm{Na}]^{+}$, experimental $m / z$ for $\mathrm{C}_{19} \mathrm{H}_{26} \mathrm{~N}_{4} \mathrm{O}_{4} \mathrm{Na}$ : 397.1837.

The synthesis of TAML-Cu'II was carried out according to the literature [50], with some improvements (Fig. 1). TAML (98.8 $\mathrm{mg}, 0.26 \mathrm{mmol}$ ) was added to a $25 \mathrm{~mL}$ round-bottom flask; then, anhydrous $\mathrm{Cu}(\mathrm{OAc})_{2}(77.6 \mathrm{mg}, 0.43 \mathrm{mmol})$, acetonitrile (10 mL), and ethyldiisopropylamine (80 drops) were added in rapid sequence. The mixed solution was heated and refluxed for $3 \mathrm{~h}$ with mechanical stirring, and the color of the suspension turned from blue to brown. The obtained solution was evaporated to dryness under vacuum, and the residue was dissolved in acetone and separated by column chromatography (using acetone as the eluent) to remove the copper salt. Then, the mixture was evaporated to dryness and extracted with an aqueous $\mathrm{NaOH}$ solution $(1 \mathrm{M}, 5 \mathrm{~mL})$. The aqueous solution was neutralized with $\mathrm{HCl}$ solution to $\mathrm{pH} 7.0$, and the formed $\mathrm{NaCl}$ was removed by flash column chromatography with acetone as eluent; the procedure yielded $142 \mathrm{mg}$ of product, still containing residual $\mathrm{NaOH}$. The latter was removed by precipitating the desired product from an aqueous solution with the addition of $n \mathrm{BuNBr}$. The cation species was then exchanged from $n$-BuN ${ }^{+}$ to $\mathrm{Na}^{+}$by a Na-form ion-exchange resin, to give $70 \mathrm{mg}$ $\mathrm{Na}$ [TAML-CuIII] (yield: 58.9\%). Characterization of TAML-Cu'III: ${ }^{1} \mathrm{H}$ NMR (400 MHz, D ${ }_{2}$ ) ): $\delta 7.80$ (dd, 2H), 6.88 (dd, 2H), 1.53 (s, $12 \mathrm{H}), 1.24$ (s, 6H); ${ }^{13} \mathrm{C}$ NMR (100 MHz, $\left.\mathrm{D}_{2} \mathrm{O}\right): \delta 183.89,178.76$, 142.85, 125.30, 120.83, 74.93, 52.12, 26.84, 25.74; HRMS (negative mode): calculated $m / z=433.0937[\mathrm{M}]^{-}$, experimental $m / z=433.0939$. The TAML-CuIII complex was recrystallized from acetone-diethyl ether, and the structure is shown in Fig. $2(a)$.

\section{Results and discussion}

Recently, we reported that redox-active ligands [14,23] can share the charge accumulation and thus avoid the formation of high-valent intermediates, such as $\mathrm{Ru}^{\mathrm{V}}$ and $\mathrm{Co}^{\mathrm{V}}$, to ensure water oxidation under a "safe condition". Cu-based molecular water oxidation catalysts [51] suffer from a large overpotential, due to the high oxidation potential of the $\mathrm{Cu}^{\mathrm{IV}} / \mathrm{Cu}^{\mathrm{III}}$ couple. On this basis, we aimed to introduce the redox-active TAML ligand to regulate the redox properties of $\mathrm{Cu}$-based catalysts. The synthesis route of TAML-Cu${ }^{\text {III }}$ is described in Fig. 1. TAML-Cu ${ }^{\text {III }}$ was characterized by ${ }^{1} \mathrm{H} /{ }^{13} \mathrm{C}$ NMR, ESI-HRMS, and single-crystal $\mathrm{X}$-ray diffraction (the details are included in the experimental section). The crystal structure of TAML-CuIII in Fig. 2(a) shows that the $\mathrm{Cu}^{\text {III }}$ center possessed a square-planar configuration coordinated with four $\mathrm{N}$ atoms, and no water or solvent molecules were coordinated with $\mathrm{Cu}^{\mathrm{III}}$ in the axial direction.

$\mathrm{CV}$ measurements of the TAML-CuIII catalyst were conducted in different types of buffer solutions including phosphate, bicarbonate, and borate. The CV plot of TAML-CuIII in phosphate buffer (0.2 M, pH 7) shown in Fig. 2(b) displays an obvious oxidation peak at $1.33 \mathrm{~V}$ (vs. NHE) with BDD as the working

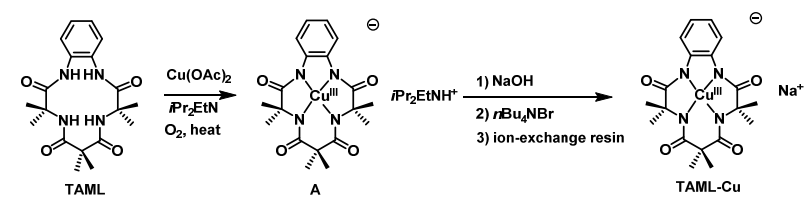

Fig. 1. Synthesis of TAML-Cu'III. 

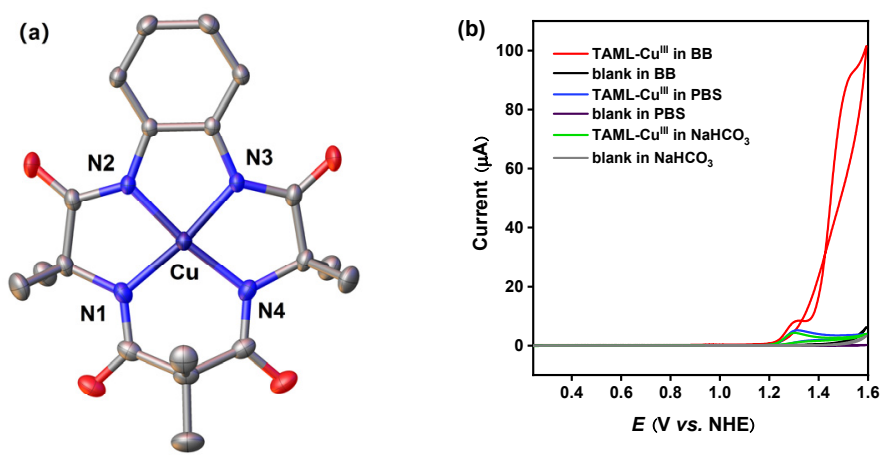

Fig. 2. (a) Crystal structure of TAML-Cu'III. All hydrogen atoms and $\mathrm{Na}^{+}$counter cations are omitted for clarity. Selected bond distances ( $\AA$ ) and angles (deg): Cu-N1 1.844(3), Cu-N2 1.816(3), Cu-N3 1.816(3); Cu-N4 1.844(3); N1-Cu-N4 100.4(2), N1-Cu-N2 86.7(3), N2-Cu-N3 85.9(8), N3-Cu-N4 86.7(3). (b) CV plots of TAML-Cu ${ }^{\mathrm{III}}(0.5 \mathrm{mM})$ in different solution types: $\mathrm{PBS}(0.2 \mathrm{M}, \mathrm{pH} 7), \mathrm{NaHCO}_{3}(0.2 \mathrm{M}, \mathrm{pH}$ 8.6), and BB (0.2 M, pH 9). Conditions: WE: BDD $\left(0.07 \mathrm{~cm}^{2}\right)$, RE: SCE, CE: platinum, scan rate: $5 \mathrm{mV} / \mathrm{s}$.

electrode (blue line). This oxidation peak was consistent with the oxidation of the TAML ligand reported in our previous work [23]. However, there was no obvious current increase when the potential was near $1.6 \mathrm{~V}$, compared to the current in the blank solution without the catalyst. Similarly, no catalytic activity was detected even at a high potential in $\mathrm{NaHCO}_{3}$ solution (green line in Fig. 2(b)). This observation indicates that, unlike the TAML-Co ${ }^{\mathrm{III}}$ case, the ligand oxidation is not sufficient for triggering the $\mathrm{Cu}^{\mathrm{III}}$ intermediate to start the catalytic water oxidation. Interestingly, a different CV curve was recorded in the borate buffer. The CV plot of TAML-Cu' ${ }^{\text {III }}$ in the borate buffer (0.2 M, pH 9) displayed two oxidation peaks at 1.32 and $1.55 \mathrm{~V}$ (red line in Fig. 2(b)). The first peak at $1.32 \mathrm{~V}$ corresponded to the oxidation of the TAML ligand, and the current of the second wave was significantly higher than that of the blank solution; many bubbles appeared on the BDD electrode during the CV scan, indicating the likely occurrence of a catalytic water oxidation process.

Fig. 3(a) shows the $E v s$. $\mathrm{pH}$ diagram of TAML-CuIII. The potential of the first wave at $\sim 1.28 \mathrm{~V}$ was independent of the $\mathrm{pH}$
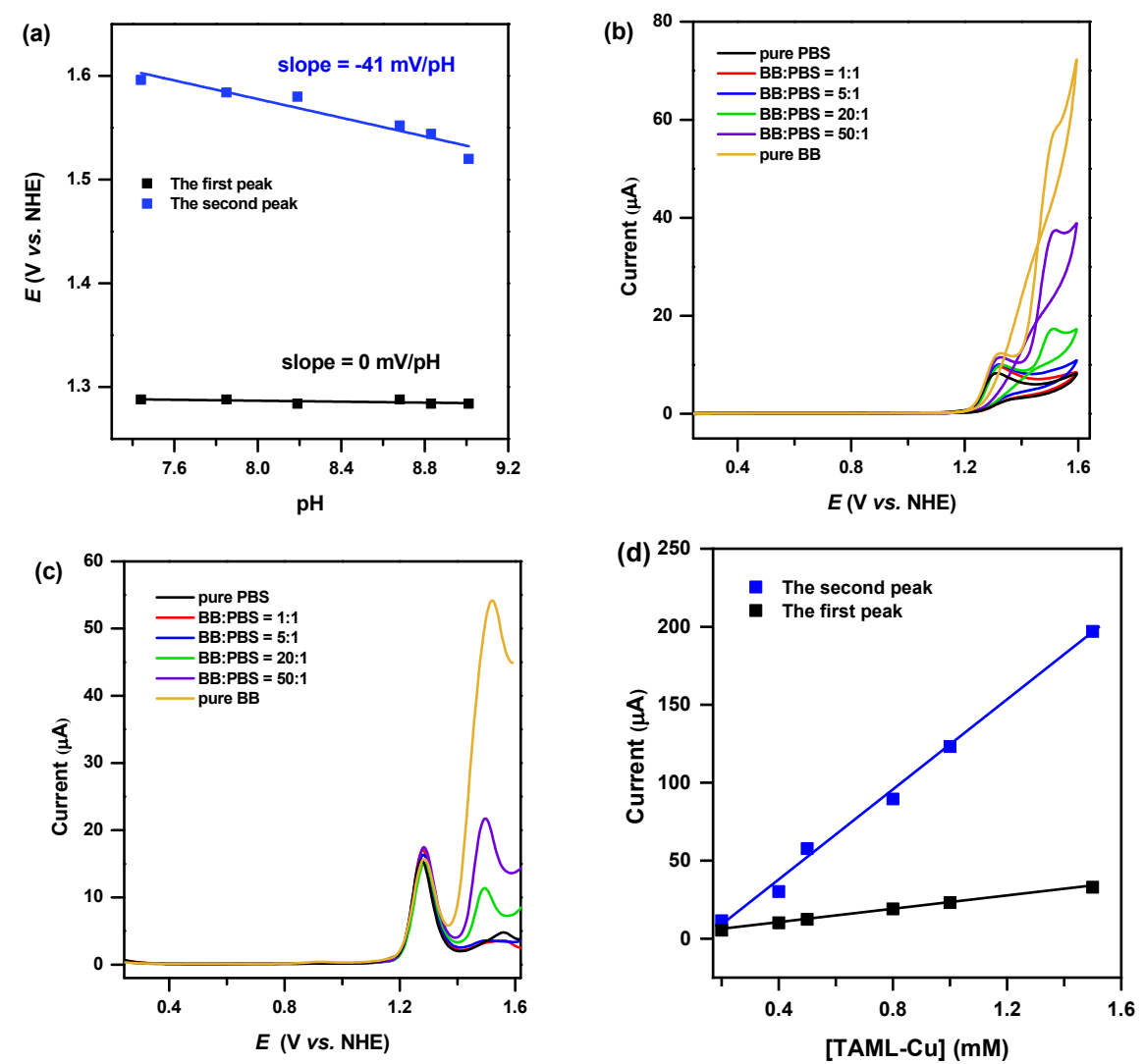

Fig. 3. (a) $E$ vs. pH diagram of TAML-Cu${ }^{\text {III }}(0.5 \mathrm{mM})$ in $\mathrm{BB}(0.2 \mathrm{M})$, with $\mathrm{pH}$ values ranging from 7.4 to 9.1. CV (b) and DPV (c) plots of TAML-Cu'II $(0.5$ $\mathrm{mM}$ ) in buffer solutions (0.2 M, pH 9) with different BB:PBS ratios. Electrochemical conditions: WE: BDD $\left(0.07 \mathrm{~cm}^{2}\right)$, RE: SCE, CE: platinum, scan rate: $10 \mathrm{mV} / \mathrm{s}$. (d) Plot of first oxidation peak currents at $\sim 1.32 \mathrm{~V}$ and second peak currents (icat) at $\sim 1.51 \mathrm{~V} v$ s. catalyst concentration ([TAML-CuIII]). 
(slope: $0 \mathrm{mV} / \mathrm{pH}$ ), indicating that a ligand-centered single-electron oxidation (Eq. (1)), rather than a ligand-centered proton-coupled electron transfer (PCET) oxidation, occurred in the presence of TAML-Co ${ }^{I I I}$ (Eq. (2)).

$$
\text { TAML-CuII } \rightarrow \text { TAML }^{++}-\mathrm{Cu}^{\mathrm{III}}+\mathrm{e}^{-}
$$

$\mathrm{TAML}-\mathrm{Co}^{\mathrm{III}}+\mathrm{H}_{2} \mathrm{O} \rightarrow \mathrm{TAML}^{2+}-\mathrm{Co}^{\mathrm{III}}-\mathrm{OH}+2 \mathrm{e}^{-}+\mathrm{H}^{+}$

The square-planar coordination mode of $\mathrm{Cu}^{\mathrm{III}}$ results in a weak interaction between $\mathrm{H}_{2} \mathrm{O}$ and the $\mathrm{Cu}^{\mathrm{III}}$ center, which prevents the occurrence of a ligand-centered two-electron PCET oxidation. According to the experimental results, the generated TAML ${ }^{+-}-\mathrm{Cu}^{\mathrm{III}}$ complex is catalytically inactive in all three buffers and its further oxidation in phosphate and bicarbonate buffers is difficult. Interestingly, the TAML ${ }^{+-}-\mathrm{Cu}^{\text {III }}$ intermediate can be further oxidized at $1.52 \mathrm{~V} v \mathrm{vs}$. NHE and thus initiate the catalytic water oxidation in borate buffer. Figs. 3(b,c) shows the electrochemical behavior of TAML-CuIII in mixed borate/phosphate buffer. The catalytic current at $1.52 \mathrm{~V}$ (vs. NHE) gradually increased with the addition of the borate buffer, and the current of the first peak of ligand oxidation remained constant. In addition, the catalytic current was also strongly dependent on the TAML-Cu${ }^{\text {III }}$ concentration (Fig. 3(d)). These results indicate that borate anions can promote the oxidation of $\mathrm{TAML}^{-+}-\mathrm{Cu}^{\mathrm{III}}$ and then initiate water oxidation. However, this is not a simple oxidative process, due to the $-41 \mathrm{mV} / \mathrm{pH}$ slope (blue line in Fig. $3(\mathrm{a}))$ and the curve-crossing phenomenon observed in the reverse CV scan (red line in Fig. 2(b)).

The curve-crossing feature of the $\mathrm{CV}$ plot likely indicates a heterogeneous catalytic process. It should be noted that nanomaterials generated in situ are the real "active species" for water oxidation. Fig. 4(a) shows the current density vs. time CPE curve in the catalyst solution. The current density gradually increased and stabilized at $1.4 \mathrm{~mA} / \mathrm{cm}^{2}$ after $10000 \mathrm{~s}$ of CPE, suggesting that the dominant active species was not initially present and that TAML-CuIII transformed into a more active species under the applied catalytic conditions. The color of the used ITO electrode changed from colorless to dark and still displayed a significant catalytic performance $\left(1.5 \mathrm{~mA} / \mathrm{cm}^{2}\right)$ in blank borate buffer, indicating that the real active species was coated on the ITO surface. The oxygen evolution by the coated ITO electrode in blank borate buffer was further confirmed in Fig. 4(b). The coated ITO electrode showed a stable current response (Fig. 4(a), black line), as well as an oxygen evolution with $88 \%$ Faradaic efficiency during electrolysis in blank buffer, indicating that the coated ITO electrode exhibited a stable catalytic activity for water oxidation.

The coated ITO electrode was further characterized by SEM and XPS. Compared to the SEM image of the ITO electrode before CPE (Fig. 5(a)), the surface topography of the coated ITO (Fig. 5(b)) was completely changed, and an amorphous deposited layer was found. The side-view SEM image in Fig. 5(c) shows that the average thickness of the coated film on the ITO substrate $(10 \mathrm{~h} \mathrm{CPE}$ at $1.39 \mathrm{~V})$ was $\sim 250 \mathrm{~nm}$. This thickness of the coated film was of the same order of magnitude as that of a previously reported film generated from simple $\mathrm{Cu}^{2+}$ in borate buffer [52]. The energy dispersive X-ray (EDX) analysis of the coated ITO film (Fig. 5(d)) confirmed the presence of $\mathrm{Cu}$ element in the coated film. The XPS spectrum of the coated ITO film in Fig. 5(e) shows two satellite peaks at 942.7 and 962.7 $\mathrm{eV}$, indicating that the $\mathrm{Cu}(\mathrm{II})$ species was formed on the ITO surface. In addition, the peaks at 954.3 and $933.9 \mathrm{eV}$ were assigned to the $\mathrm{Cu} 2 p_{1 / 2}$ and $\mathrm{Cu} 2 p_{3 / 2}$ levels of $\mathrm{CuO}$ species $[52,53]$. Fig. 5 (f) shows the characteristic peak of B $1 s$, denoting the presence of boron on the coated ITO. The overall XPS spectrum revealed that the $\mathrm{Cu} / \mathrm{B} / 0$ ratio was $1: 1.32: 3$, indicating that boron-doped $\mathrm{CuO}_{x}\left(\mathrm{~B} / \mathrm{CuO}_{x}\right)$ was the true active species.

The stability of the $\mathrm{B} / \mathrm{CuO}_{x}$ film was further studied in different types of buffer solutions. Fig. 6 shows that the CPE current of the $\mathrm{B} / \mathrm{CuO}_{x}$ film in borate buffer $(0.2 \mathrm{M}, \mathrm{pH}$ 9) was maintained at $2 \mathrm{~mA} / \mathrm{cm}^{2}$, whereas it rapidly decreased in phosphate buffer and $\mathrm{NaHCO}_{3}$ solution, implying that the borate anion plays a key role not only in the $\mathrm{B} / \mathrm{CuO}_{x}$ formation, but also in maintaining the stability of the coated film in the
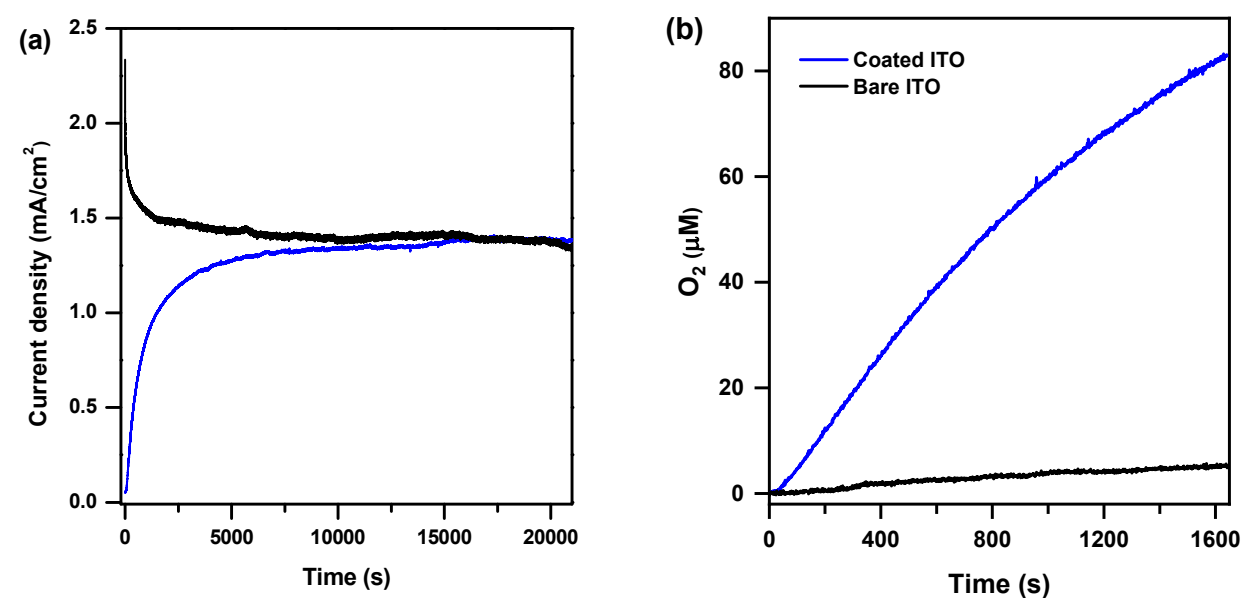

Fig. 4. (a) CPE curve of (blue line) TAML-Cu ${ }^{I I I}(0.5 \mathrm{mM}, 3 \mathrm{~mL})$ in $\mathrm{BB}(0.2 \mathrm{M}, \mathrm{pH}$ 9) using ITO as working electrode; the black line represents the CPE curve of the used ITO after $20000 \mathrm{~s}$ CPE in BB containing TAML-Cülil, followed by rinsing with deionized water and immediate transfer to the BB without catalyst. Electrochemical conditions: WE: ITO $\left(1 \mathrm{~cm}^{2}\right)$, RE: SCE, CE: platinum, applied potential: $1.39 \mathrm{~V} v$ s. NHE. (b) $\mathrm{O}_{2}$ evolution curves during $\mathrm{CPE}$ at $1.39 \mathrm{~V}$ of bare ITO (black line) and coated ITO (blue line) in BB (0.2 M, pH 9), measured with a $\mathrm{O}_{2}$ detector (calibrated Ocean Optics FOXY probe). 

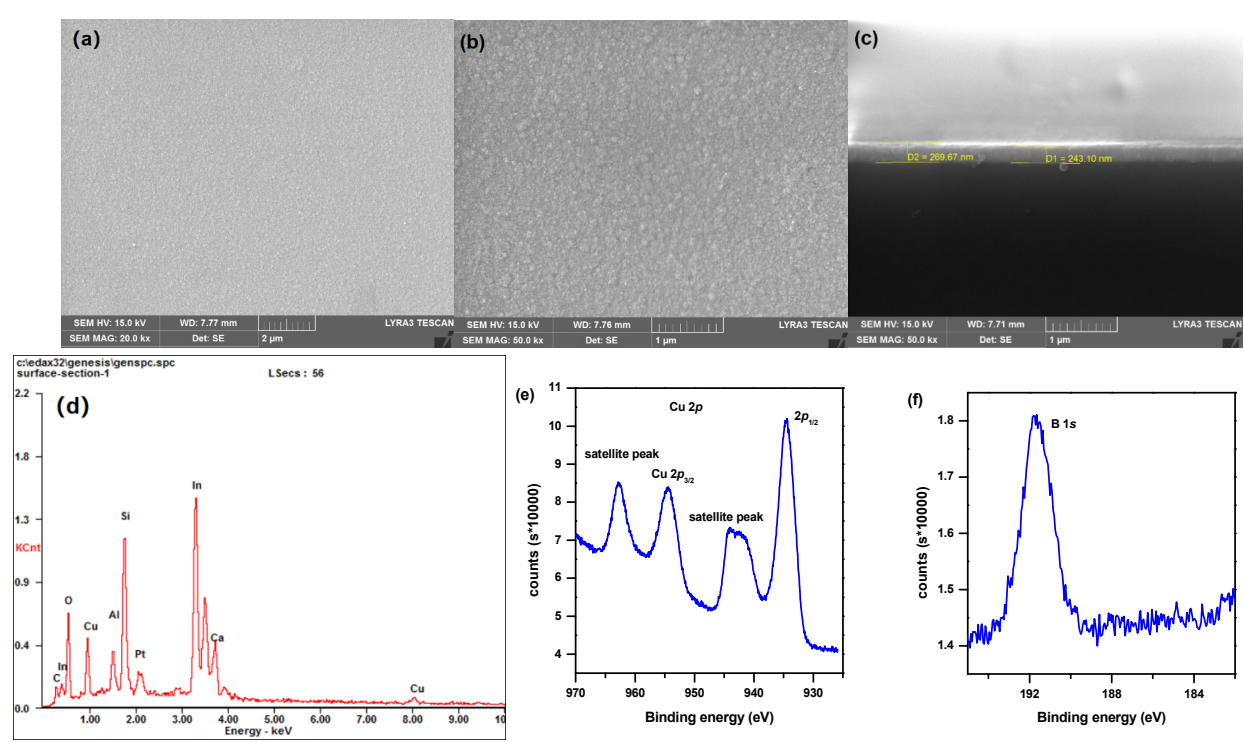

Fig. 5. SEM image (top view) of ITO before (a) and after (b) $10 \mathrm{~h}$ of CPE in BB (0.2 M, pH 9) containing TAML-Cu'II catalyst (0.5 mM). Electrochemical conditions: WE: ITO $\left(1 \mathrm{~cm}^{2}\right)$, RE: SC, CE: platinum, applied potential: $1.39 \mathrm{~V}$ vs. NHE. (c) SEM image (side view) of generated B/CuO film on ITO electrode. (d) EDX analysis of generated $\mathrm{B} / \mathrm{CuO}_{x}$ film. XPS profiles of $\mathrm{Cu} 2 p(\mathrm{e})$ and $\mathrm{B} 1 s$ (f) levels of generated $\mathrm{B} / \mathrm{CuO}_{x}$ film.
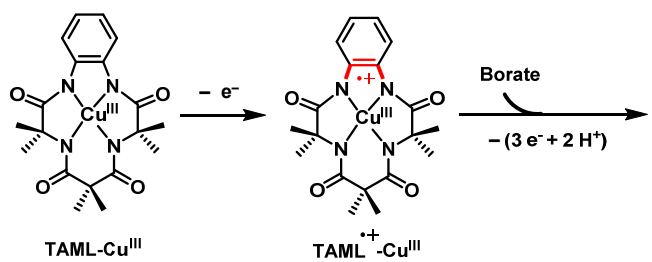

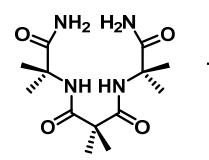

D1

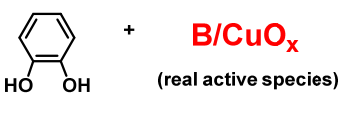

D2

Fig. 7. Proposed decomposition mechanism of TAML-Cu${ }^{\mathrm{III}}$ for electro-catalyzing water oxidation in borate buffer.

catalytic process.

In order to further understand how borate anions promote the formation of the $\mathrm{B} / \mathrm{CuO}_{x}$ species, product analysis was performed after $10 \mathrm{~h}$ of $\mathrm{CPE}$ with TAML-Cu${ }^{\mathrm{III}}$ at $1.39 \mathrm{~V}$ in borate buffer. After CPE, the main HRMS (positive mode) peak was found at $m / z=323.1668$, which was consistent with the $m / z$ value of the D1 species (calculated $m / z=323.1690$, [D1 + Na] ${ }^{+}$) in Fig. 7. Combined with the $\mathrm{pH}$ dependence of the second wave $(-41 \mathrm{mV} / \mathrm{pH}$ slope, Fig. 3(a)), we can conclude that borate anions can promote further oxidation of $\mathrm{TAML}^{-+}-\mathrm{Cu}^{\mathrm{III}}$ and subse-

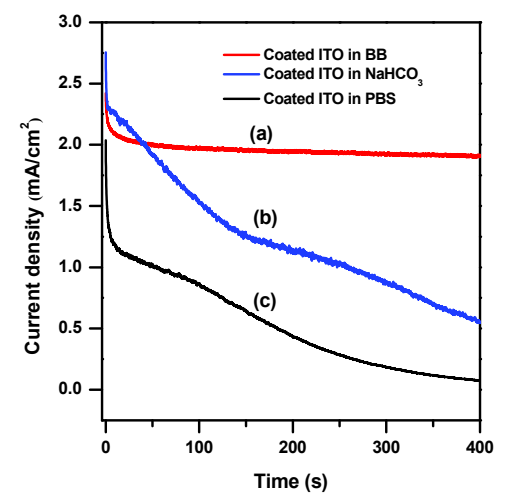

Fig. 6. CPE curves of coated $\mathrm{B} / \mathrm{CuO}_{x}$ film on ITO electrode in different types of buffer solutions. (a) borate buffer (red line, $0.2 \mathrm{M}, \mathrm{pH}$ 9); (b) $\mathrm{NaHCO}_{3}$ solution (blue line, $0.2 \mathrm{M}, \mathrm{pH}$ 9); (c) PBS (black line, $0.2 \mathrm{M}, \mathrm{pH}$ 9). quent hydrolysis of the ligand to achieve the deposition of $\mathrm{B} / \mathrm{CuO}_{x}$ on the electrode surface (Fig. 7). In this mechanism, the borate buffer not only promotes imide hydrolysis, but also contributes to the generation of the active $\mathrm{B} / \mathrm{CuO}_{x}$ species. In this case, the borate buffer plays a completely different role from phosphate and bicarbonate, indicating that the choice of the buffer solution is critical for the catalytic behavior and performance of the catalyst [52,54-56].

\section{Conclusions}

In this work, we investigated the redox properties of TAML-Cu ${ }^{\text {III }}$ in three types of buffers. TAML-Cu ${ }^{\text {III }}$ can be oxidized by ligand-centered oxidation to give $\mathrm{TAML}^{\bullet+}-\mathrm{Cu}^{\mathrm{III}}$, which cannot interact with water and undergo further oxidation. However, in the presence of borate ions, $\mathrm{TAML}^{\cdot+}{ }^{+} \mathrm{Cu}^{\mathrm{III}}$ can undergo further oxidation with the hydrolysis of the ligand, and at the same time a robust active catalyst for water oxidation, $\mathrm{B} / \mathrm{CuO}_{x}$, is formed in situ. Two main conclusions could be drawn: (1) a square-planar $\mathrm{Cu}^{\mathrm{III}}$ complex is not an effective structure for water oxidation catalysis; (2) buffer anions can play a key role in the decomposition of molecular pre-catalysts. Therefore, when assessing whether a potential complex exhibits catalytic activity for water oxidation, special attention must be paid to the influence of the buffer anions on the catalytic performance and stability. 


\section{Conflicts of interest}

There are no conflicts to declare.

\section{References}

[1] T. J. Meyer, Nature, 2008, 451, 778-779.

[2] N. S. Lewis, D. G. Nocera, Proc. Natl Acad. Sci. USA, 2006, 103, 15729-15735.

[3] M. G. Walter, E. L. Warren, J. R. McKone, S. W. Boettcher, Q. Mi, E. A. Santori, N. S. Lewis, Chem. Rev., 2010, 110, 6446-6473.

[4] F. Liu, J. J. Concepcion, J. W. Jurss, T. Cardolaccia, J. L. Templeton, T. J. Meyer, Inorg. Chem., 2008, 47, 1727-1752.

[5] J. D. Blakemore, R. H. Crabtree, G. W. Brudvig, Chem. Rev., 2015, 115, 12974-13005.

[6] C. J. Gagliardi, A. K. Vannucci, J. J. Concepcion, Z. Chen, T. J. Meyer, Energy Environ. Sci., 2012, 5, 7704-7717.

[7] J. A. Gilbert, D. S. Eggleston, W. R. Murphy, D. A. Geselowitz, S. W. Gersten, D. J. Hodgson, T. J. Meyer, J. Am. Chem. Soc., 1985, 107, 3855-3864.

[8] Y. Lei, J. K. Hurst, Inorg. Chem., 1994, 33, 4460-4467.

[9] C. Sens, I. Romero, M. Rodriguez, A. Llobet, T. Parella, J. Benet-Buchholz, J. Am. Chem. Soc., 2004, 126, 7798-7799.

[10] R. Zong, R. P. Thummel, J. Am. Chem. Soc., 2005, 127, 12802-12803.

[11] J. J. Concepcion, J. W. Jurss, J. L. Templeton, T. J. Meyer, J. Am. Chem. Soc., 2008, 130, 16462-16463.

[12] L. Duan, A. Fischer, Y. Xu, L. Sun, J. Am. Chem. Soc., 2009, 131, 10397-10399.

[13] L. Duan, F. Bozoglian, S. Mandal, B. Stewart, T. Privalov, A. Llobet, L. Sun, Nat. Chem., 2012, 4, 418-423.

[14] J. Shi, Y. H. Guo, F. Xie, Q. F. Chen, M. T. Zhang, Angew. Chem. Int. Ed., 2020, 59, 4000-4008.

[15] N. D. McDaniel, F. J. Coughlin, L. L. Tinker, S. Bernhard, J. Am. Chem. Soc., 2008, 130, 210-217.

[16] Laia Vilella, Pietro Vidossich, David Balcells, A. Lledós, Dalton Trans., 2011, 40, 11241-11247.
[17] Y. Naruta, M. Sasayama, T. Sasaki, Angew. Chem. Int. Ed., 1994, 33, 1839-1841.

[18] J. Limburg, J. S. Vrettos, L. M. Liable-Sands, A. L. Rheingold, R. H. Crabtree, G. W. Brudvig, Science, 1999, 283, 1524-1527.

[19] W. C. Ellis, N. D. McDaniel, S. Bernhard, T. J. Collins, J. Am. Chem. Soc., 2010, 132, 10990-10991.

[20] J. L. Fillol, Z. Codolà, I. Garcia-Bosch, L. Gomez, J. J. Pla, M. Costas, Nat. Chem., 2011, 3, 807-813.

[21] M. Okamura, M. Kondo, R. Kuga, Y. Kurashige, T. Yanai, S. Hayami, V. K. Praneeth, M. Yoshida, K. Yoneda, S. Kawata, S. Masaoka, Nature, 2016, 530, 465-468.

[22] D. J. Wasylenko, C. Ganesamoorthy, J. Borau-Garcia, C. P. Berlinguette, Chem. Commun., 2011, 47, 4249-4251.

[23] H. Y. Du, S. C. Chen, X. J. Su, L. Jiao, M. T. Zhang, J. Am. Chem. Soc., 2018, 140, 1557-1565.

[24] M. Zhang, M. T. Zhang, C. Hou, Z. F. Ke, T. B. Lu, Angew. Chem. Int. Ed., 2014, 53, 13042-13048.

[25] Y. Han, Y. Wu, W. Lai, R. Cao, Inorg. Chem., 2015, 54, 5604-5613.

[26] L. Wang, L. Duan, R. B. Ambre, Q. Daniel, H. Chen, J. Sun, B. Das, A. Thapper, J. Uhlig, P. Dinér, L. Sun, J. Catal., 2016, 335, 72-78.

[27] S. M. Barnett, K. I. Goldberg, J. M. Mayer, Nat. Chem., 2012, 4, 498-502.

[28] M. T. Zhang, Z. Chen, P. Kang, T. J. Meyer, J. Am. Chem. Soc., 2013, 135, 2048-2051.

[29] X. J. Su, M. Gao, L. Jiao, R. Z. Liao, P. E. Siegbahn, J. P. Cheng, M. T. Zhang, Angew. Chem. Int. Ed., 2015, 54, 4909-4914.

[30] F. Yu, F. Li, J. Hu, L. Bai, Y. Zhu, L. Sun, Chem. Commun., 2016, 52, 10377-10380.

[31] F. Chen, N. Wang, H. Lei, D. Guo, H. Liu, Z. Zhang, W. Zhang, W. Lai, R. Cao, Inorg. Chem., 2017, 56, 13368-13375.

[32] Q. Q. Hu, X. J. Su, M. T. Zhang, Inorg. Chem., 2018, 57, 10481-10484.

[33] X. Jiang, J. Li, B. Yang, X. Z. Wei, B. W. Dong, Y. Kao, M. Y. Huang, C. H. Tung, L. Z. Wu, Angew. Chem. Int. Ed., 2018, 57, 7850-7854.

[34] X. J. Su, C. Zheng, Q. Q. Hu, H. Y. Du, R. Z. Liao, M. T. Zhang, Dalton Trans., 2018, 47, 8670-8675.

[35] Y. Liu, Y. Han, Z. Zhang, W. Zhang, W. Lai, Y. Wang, R. Cao, Chem Sci, 2019, 10, 2613-2622.

\section{Graphical Abstract}

Chin. J. Catal., 2021, 42: 1338-1344 doi: 10.1016/S1872-2067(20)63729-9

Buffer anion effects on water oxidation catalysis: The case of $\mathrm{Cu}(\mathrm{III})$ complex

Qifa Chen, Haoyi Du, Mingtian Zhang*

Tsinghua University

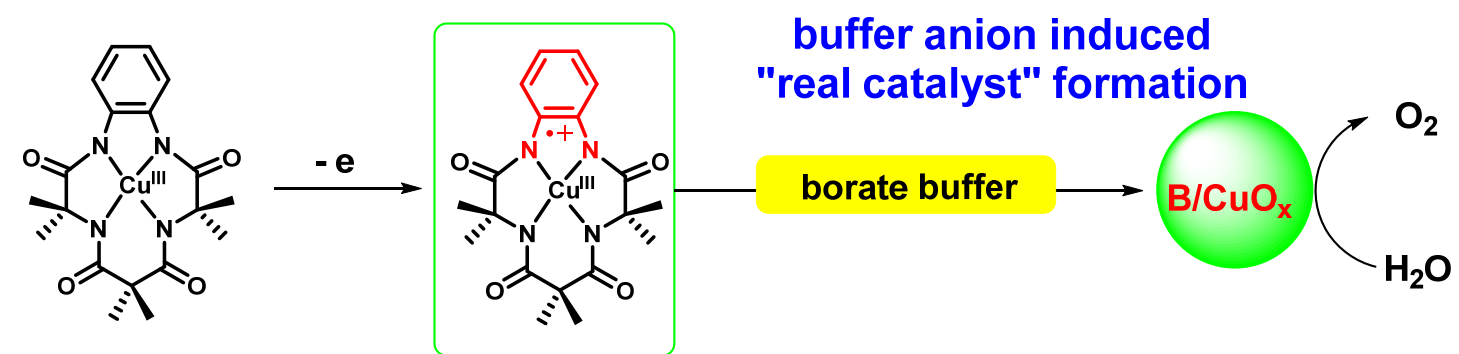

In this work, the effect of buffer anions on the catalytic performance and stability of a molecular catalyst (TAML-CuII) was investigated. TAML-CuIII showed catalytic activity for water oxidation in borate buffer, where it triggered the formation of a heterogeneous active species, $\mathrm{B} / \mathrm{CuO}_{x}$, by a macrocyclic ligand open-ring reaction. 
[36] S. W. Gersten, G. J. Samuels, T. J. Meyer, J. Am. Chem. Soc., 1982, 104, 4029-4030.

[37] M. D. Kärkäs, O. Verho, E. V. Johnston, B. Åkermark, Chem. Rev., 2014, 114, 11863-12001.

[38] N. Cox, D. A. Pantazis, F. Neese, W. Lubitz, Acc. Chem. Res., 2013, $46,1588-1596$.

[39] X. Sala, S. Maji, R. Bofill, J. Garcia-Anton, L. Escriche, A. Llobet, Acc. Chem. Res., 2014, 47, 504-516.

[40] M. D. Kärkäs, B. Åkermark, Dalton Trans., 2016, 45, 14421-14461.

[41] N. Wang, H. Zheng, W. Zhang, R. Cao, Chin. J. Catal., 2018, 39, 228-244.

[42] R. Matheu, M. Z. Ertem, C. Gimbert-Surinach, X. Sala, A. Llobet, Chem. Rev., 2019, 119, 3453-3471.

[43] A. Singh, L. Spiccia, Coord. Chem. Rev., 2013, 257, 2607-2622.

[44] M. D. Kärkäs, E. V. Johnston, O. Verho, B. Akermark, Acc. Chem. Res., 2014, 47, 100-111.

[45] B. M. Hunter, H. B. Gray, A. M. Muller, Chem. Rev., 2016, 116, 14120-14136.

[46] M. M. Najafpour, G. Renger, M. Holynska, A. N. Moghaddam, E. M.
Aro, R. Carpentier, H. Nishihara, J. J. Eaton-Rye, J. R. Shen, S. I. Allakhverdiev, Chem. Rev., 2016, 116, 2886-2936.

[47] M. A. Asraf, H. A. Younus, M. Yusubov, F. Verpoort, Catal. Sci. Technol., 2015, 5, 4901-4925.

[48] T. J. Collins, R. D. Powell, C. Slebodnick, E. S. Uffelman, J. Am. Chem. Soc., 1991, 113, 8419-8425.

[49] M. A. DeNardo, M. R. Mills, A. D. Ryabov, T. J. Collins, J. Am. Chem. Soc., 2016, 138, 2933-2936.

[50] E. S. Uffelman, J. R. Doherty, C. Schultze, A. L. Burke, K. R. Bonnema, T. T. Watson, D. W. Lee, J. Chem. Educ., 2004, 81, 182-185.

[51] D. Lukács, Ł. Szyrwiel, J. Pap, Catalysts, 2019, 9, 83.

[52] F. Yu, F. Li, B. Zhang, H. Li, L. Sun, ACS Catal., 2015, 5, 627-630.

[53] T. T. Li, S. Cao, C. Yang, Y. Chen, X. J. Lv, W. F. Fu, Inorg. Chem., 2015, 54, 3061-3067.

[54] Z. Chen, T. J. Meyer, Angew. Chem. Int. Ed., 2013, 52, 700-703.

[55] M. Dinca, Y. Surendranath, D. G. Nocera, Proc. Natl. Acad. Sci. USA, 2010, 107, 10337-10341.

[56] D. K. Bediako, B. Lassalle-Kaiser, Y. Surendranath, J. Yano, V. K. Yachandra, D. G. Nocera, J. Am. Chem. Soc., 2012, 134, 6801-6809.

\title{
缓冲溶液阴离子对三价铜催化剂催化水氧化过程的影响
}

\author{
陈齐发, 杜昊易, 章名田 ${ }^{*}$ \\ 清华大学化学系基础分子科学中心, 北京 100084
}

摘要: 水氧化是光解水制氢气的瓶颈反应, 认识和理解水氧化机制并研发廉价稳定的催化剂对解决这一问题尤为重要. 自 1982年Meyer课题组报道了第一例分子型双核钓水氧化催化剂(blue dimer) 以来, 过渡金属配合物被广泛应用于探索这一氧 化过程的规律和机理, 特别是近几年廉价金属配合物在水氧化领域的应用也备受关注. 由于水氧化一般在苛刻的氧化条 件下才可以实现, 如何提高过渡金属配合物在催化条件下的稳定性一直是分子催化剂结构设计的一个难点. 利用部分分 子催化剂的不稳定性, 将其作为前体制备非均相金属氧化物催化剂, 广泛用于水氧化研究. 然而, 对于催化水氧化过程中 造成分子催化剂不稳定的因素却鲜有探讨. 因此, 了解分子催化剂和异相活性物种之间原位转化的机理对于分子催化剂 设计至关重要.

本文考察了大环配体(TAML)的三价铜配合物 $\left(\mathrm{TAML}-\mathrm{Cu}^{\mathrm{III}}\right)$ 的氧化还原性质及其电催化水氧化的反应性能. 实验结果 表明, TAML-Cu ${ }^{\text {III }}$ 的催化水氧化活性与缓冲溶液种类有关, 在磷酸盐溶液与碳酸氢钠溶液中均无催化活性, 而在硼酸溶液 中表现出较高的催化活性. 此外, TAML-Cu ${ }^{\mathrm{II}}$ 具有与本课题组之前报道的TAML-Co ${ }^{\mathrm{III}}$ 截然不同的电化学行为. TAML-Cu ${ }^{\mathrm{III}}$

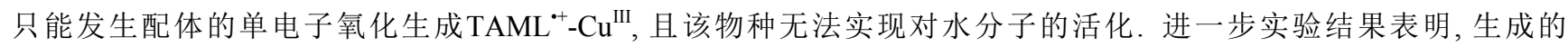
$\mathrm{TAML}^{+}-\mathrm{Cu}^{\mathrm{III}}$ 在嗍酸根的协助下可以发生进一步氧化和配体的水解, 从而生成具有高活性的非均相物种. 研究表明该活性 物种为含硼的氧化铜物种 $\left(\mathrm{B} / \mathrm{CuO}_{x}\right)$. 通过本文研究可得出两个结论: (1)具有平面四方构型的三价铜配合物不是一种有效 催化水氧化的分子型催化剂; (2)缓冲阴离子在分子催化剂的分解中起到了关键作用. 因此, 缓冲溶液的选择对催化剂的电 化学行为以及稳定性有着重要的影响.

关键词: 人工光合作用; 水氧化; 氧化还原活性配体; 铜催化剂; 缓冲溶液阴离子效应

收稿日期: 2020-09-05. 接受日期: 2020-10-14. 上网时间: 2021-04-05.

*通讯联系人. 电话: (010)62783624; 电子信箱: mtzhang@mail.tsinghua.edu.cn

基金来源：国家自然科学基金(21661132006,219330007).

本文的电子版全文由Elsevier出版社在ScienceDirect上出版(http://www.sciencedirect.com/journal/chinese-journal-of-catalysis). 